\title{
Genetic population structure of minke whales Balaenoptera acutorostrata from Greenland, the North East Atlantic and the North Sea probably reflects different ecological regions
}

\author{
Liselotte W. Andersen ${ }^{1,2,6, *}$, Erik W. Born ${ }^{2}$, Rune Dietz ${ }^{3}$, Tore Haug ${ }^{4}$, Nils Øien ${ }^{5}$, \\ Christian Bendixen ${ }^{1}$ \\ ${ }^{1}$ Danish Institute for Agricultural Sciences, Molecular Genetics, PO Box 50, 8830 Tjele, Denmark \\ ${ }^{2}$ Greenland Institute of Natural Resources, PO Box 570, 3900 Nuuk, Greenland \\ ${ }^{3}$ National Environmental Research Institute, Department of Arctic Environment, PO Box 358, 4000 Roskilde, Denmark \\ ${ }^{4}$ Centre of Marine Resources, Fiskeriforskning, University of Tromsø, 9037 Tromsø, Norway \\ ${ }^{5}$ Marine Research Institute, PO Box 1870, 5817 Bergen, Norway
}

${ }^{6}$ Present address: National Environmental Research Institute, Department of Coastal Zone Ecology, Grenåvej 12, 8410 Rønde, Denmark

\begin{abstract}
A genetic study to determine the population structure of minke whales Balaenoptera acutorostrata in Greenland, the Central and NE Atlantic and the North Sea was carried out on a sample of 306 individuals. Samples were analysed by sequencing the D-loop in mtDNA and using 16 polymorphic nuclear microsatellite markers. Muscle samples from a total of 154 minke whales, caught between 6 May and 31 October 1998 by Greenland and Norwegian licensed whalers within 6 areas of the North Atlantic, were analysed (West Greenland, $\mathrm{n}=44$; Jan Mayen, $\mathrm{n}=24$; Svalbard, $\mathrm{n}$ $=16$; the Barents Sea, $\mathrm{n}=33$; Vesterålen/Lofoten on the coast of northwestern Norway, $\mathrm{n}=14$, and the North Sea, $\mathrm{n}=23$ ). In addition, 30 minke whales sampled in East Greenland during 1996, 1997 and 1999 were included. Furthermore, 122 minke whales caught in West Greenland in 3 different years $(1982,1996$ and 1997) were analysed to determine potential inter-annual variation within a sampling area. The lack of inter-annual variation in West Greenland suggests that the minke whales summering in the area year after year belong to the same sub-population. The study indicated the existence of 4 genetically differentiated sub-populations: (1) West Greenland, (2) Central North Atlantic-East Greenland-Jan Mayen area, (3) NE Atlantic (Svalbard, the Barents Sea and northwestern Norway), and (4) North Sea. It is suggested that these sub-populations have been isolated by discontinuities between regions, i.e. each of the sub-populations has evolved in response to regional differences in ecological conditions (oceanography, ice cover, prey type and prey availability).
\end{abstract}

KEY WORDS: North Atlantic $\cdot$ Minke whale $\cdot$ Balaenoptera acutorostrata $\cdot$ Microsatellites $\cdot$ mtDNA Population structure

Resale or republication not permitted without written consent of the publisher

\section{INTRODUCTION}

Most baleen whales feed in the summer months in the fertile cold waters towards the poles, having migrated from winter breeding grounds in warmer latitudes. During winter, when pairing and birth of calves take place, they apparently feed, if at all, at lower latitudes - perhaps in the subtropics (Mackintosh 1965, Jonsgård 1966, Horwood 1989). Although their wintering grounds have not been identified with certainty, minke whales Balaenoptera acutorostrata seem to fit into this general ecological pattern of large cetaceans (cf. Horwood 1989, Kasamatsu et al. 1995). 
In the northern hemisphere, no one organism forms the dominant food supply for minke whales. The greater variety of food in the northern hemisphere as compared to that in the southern can be partly attributed to the more complex topography and water conditions (Mackintosh 1965). In the North Atlantic region minke whales concentrate in traditional summer feeding grounds off Newfoundland-Labrador, off West and Southeast Greenland, around Iceland and Jan Mayen, off Svalbard and in the Barents Sea, off western Norway and in the North Sea (Horwood 1989). Hence, although minke whales may occur in deeper waters during summer (Anonymous 1998) they tend to feed in shallow continental shelf areas. These are areas of great productivity due to upwelling and mixing of water masses of different origin (Mann \& Lazier 1991).

The range covered by the present study extends from the west coast of Greenland across the Atlantic Ocean to Svalbard, the Barents Sea in the north and the North Sea in the south (Fig. 1). Within this range, the areas where the minke whales concentrate during summer differ substantially with respect to oceanography-water circulation, water temperatures and ice cover (Mann \& Lazier 1991): (1) The West Greenland area is influenced by a mixture of waters from the cold East Greenland Current and the warmer and more saline Irminger Current. (2) The East Greenland and Jan Mayen area is dominated by the East Greenland Current that brings cold low-saline polar water south along the eastern coast of Greenland resulting in heavy pack ice almost all year round. (3) The western coast of Svalbard is an area of mixing between polar water and a branch of the warm North Atlantic Current. (4) The Barents Sea is a relatively shallow area that is dominated by the North Atlantic Current (these latter 2 areas are ice-covered for part of the year). (5) The northwestern coast of Norway is greatly influenced by the North Atlantic Current and the Norwegian Coastal Current resulting in relatively high water temperatures. (6) The North Sea is confined between the British Isles, southern Norway and Denmark, and is influenced by water from the North Atlantic Current as

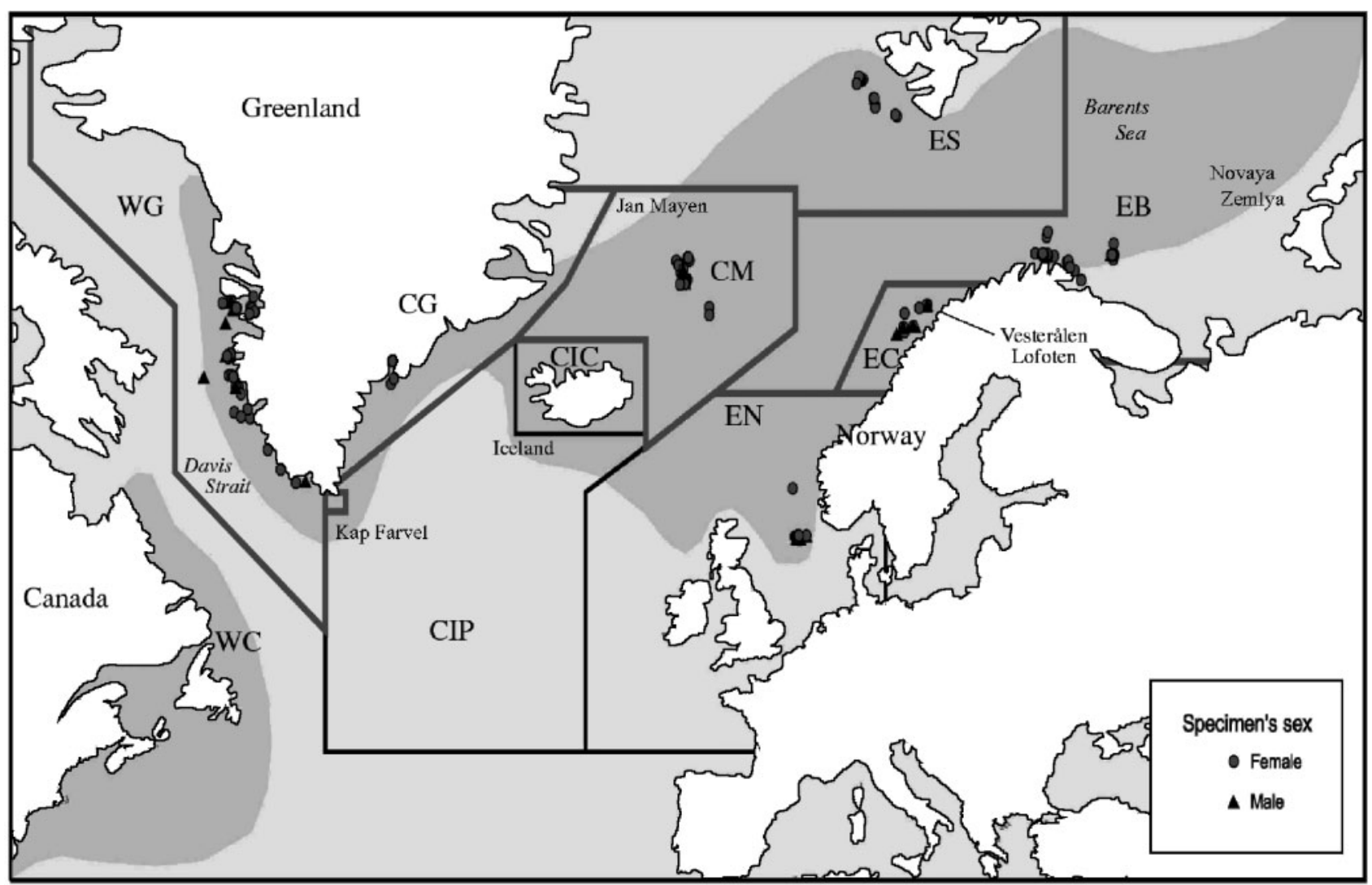

Fig. 1. Map showing boundaries of International Whaling Commission 'small areas' (Anonymous 1993) showing 1998 sampling locations. Samples in the present study were collected in West Greenland (WG), Central Eastern Greenland (CG), Central Jan Mayen (CM), East Svalbard (ES), East Barents Sea (EB), East Coastal Norway i.e. Vesterålen/Lofoten (EC) and East North Sea (EN). No samples from Central Iceland Coastal (CIC), Central Iceland Pelagic (CIP) and West Canada (WC) were included in the present analysis. Darker grey shading indicates approximate summer distribution area of minke whales. It is not known whether or not the distribution is connected between Canada and Western Greenland 
well as land runoff from the surrounding countries. Ice is never present along western Norway and in the North Sea.

These regions also differ with respect to fish and crustacean fauna as reflected in the differences between areas in minke whale prey preferences. Capelin Mallotus villosus and sand eel Ammodytes sp. are important food for minke whales in West Greenland waters, whereas polar cod Boreogadus saida seems to be of greater importance in the East Greenland region (Neve 2000). Krill Thysanoessa sp. and herring Clupea harengus are 2 of the most prominent prey items in the diet of minke whales in the Northeast Atlantic where gadoid fish (cod Gadus morhua, saithe Pollachius virens, and haddock Melanogrammus aeglefinus) are also important prey (Haug et al. 2002). Within the NE Atlantic there are regional differences in prey preferences. Consumption of herring is almost exclusively confined to the Barents Sea and the northwestern coast of Norway whereas consumption of krill is more pronounced in the Svalbard area (Folkow et al. 2000, Haug et al. 2002). In the latter area, capelin was important prior to the collapse of the Barents Sea capelin stock in 1992-93 (ibid.). In 1999, herring was a predominant food item in the Norwegian Sea whereas sand eel dominated the minke whale food in the North Sea. In this latter area, mackerel Scomber scombrus and other fish (e.g. herring) constituted the remainder of food items (Olsen \& Holst 2002).

We hypothesised that profound ecological differences between the summer foraging areas of minke whales in the North Atlantic, and the affinity of the whales to specific foraging grounds, have resulted in the development of genetically discrete groups of minke whales. The existence of genetically differentiated groups of whales at summer feeding grounds was indicated in studies of North Atlantic humpback whales Megaptera novaeanglia (Baker et al. 1994, Palsbøll et al. 1995).

Previous studies applying various genetic techniques found indications of population sub-structuring in North Atlantic minke whales (Palsbøll 1989, Árnason \& Spillaert 1991, Danielsdóttir et al. 1992, 1995, Bakke et al. 1996, Martinez et al. 1997, Martinez \& Pastene 1999). However, as these studies included samples taken in different years, it is unclear to what extent inter-annual variation influenced spatial comparisons.

In this paper we report analyses of both mitochondrial DNA (mtDNA D-loop sequences) and nuclear DNA (16 DNA microsatellite loci) obtained from a total of 306 minke whales from 7 sampling areas in the North Atlantic region (Fig. 1) to test the basic hypothesis: Are major ecological differences among the waters of West Greenland, the East Greenland-Jan Mayen area, the NE Atlantic and the North Sea reflected in genetic variation among minke whales summering in these areas?

To minimise or exclude the potential influence of using samples taken in different years, we tested samples that had been collected during only 1 year (1998). Furthermore, to explore the possible effects of interannual variation, samples taken in other years in West Greenland were also included.

\section{MATERIALS AND METHODS}

Sampling areas. For management purposes, the International Whaling Commission (IWC) subdivided the summer range of North Atlantic minke whales into 10 management areas referred to as 'IWC small areas' (Anonymous 1992) (Fig. 1). Currently, Greenland catches minke whales in the 'small areas' West Greenland (WG) and Central Eastern Greenland (CG) on the east coast of Greenland, whereas Norway catches minke whales in Central Jan Mayen (CM), East Svalbard (ES), East Barents Sea (EB), East Coastal Norway (i.e. the Vesterålen/Lofoten area; EC) and East North Sea (EN) (Fig. 1). Various combinations of samples from these 7 areas were tested against each other to explore the relationships between genetic population structure and the ecological regions from which the samples were taken (see 'Data analysis'). The combination of samples from ES, EB and EC are here denoted as 'NE Atlantic' (NE), and the pooled samples from West Greenland in 1982, 1996, 1997 and 1998 are denoted 'WG total'.

Collection of samples in the field, extraction of DNA and sex determination. The number of samples in this study broken down by area, year, sex and season of collection is shown in Table 1. Two sets of muscle samples were used: (1) Samples obtained in 1998 from a total of 154 minke whales caught in 6 IWC small areas (WG, CM, ES, EB, EC, EN) (Fig. 1, Table 1), and (2) samples from a total of 152 minke whales taken in other years $(1982,1996,1997,1999)$ in WG and eastern Greenland (CG) (Table 1).

(1) In Greenland, hunters licensed by the Greenland Home Rule authorities to take minke whales in 1998 collected the muscle samples used in the present study. Similar samples were collected by trained staff during the Norwegian small-type whaling operations in 1998. The Greenland hunters were instructed on how to take the samples and requested to provide information on special forms about the date and location of the kill plus information on sex and body length. Similar data were available for the Norwegian samples. A total of 44 individuals collected between 6 May and 31 October 1998 from WG were included in the analyses (Table 1). Samples were collected from 110 minke whales taken in 1998 during the Norwegian catches 
Table 1. Balaenoptera acutorostrata. Number of minke whales sampled in 1982, 1996, 1997, 1998 and 1999 from 7 International Whaling Commission (IWC) 'small areas' in Greenland, the central N Atlantic, the NE Atlantic and the North Sea, the sex composition of the samples, and the sampling periods. See Fig. 1 for locations of sample areas

\begin{tabular}{|c|c|c|c|c|c|c|c|c|}
\hline Region & Sampling area & IWC acronym & Year & Female & Male & Total & Sampling period & $\begin{array}{c}\text { Sample } \\
\text { set }\end{array}$ \\
\hline \multirow[t]{5}{*}{ W Greenland } & W Greenland & WG & 1982 & 34 & 9 & 43 & 13 June-21 August & 2 \\
\hline & W Greenland & WG & 1996 & 31 & 9 & 40 & 3 May-26 November & 2 \\
\hline & W Greenland & WG & 1997 & 28 & 11 & 39 & 14 April-18 November & 2 \\
\hline & W Greenland & WG & 1998 & 36 & 8 & 44 & 6 May-31 October & 1 \\
\hline & Total & & $1982-98$ & 129 & 37 & 166 & & \\
\hline \multirow[t]{3}{*}{ Central N Atlantic } & E Greenland & CG & $1996-99$ & 27 & 3 & 30 & 12 July-16 October & 2 \\
\hline & Jan Mayen & $\mathrm{CM}$ & 1998 & 19 & 5 & 24 & 7 June-1 July & 1 \\
\hline & Total & & $1996-98$ & 46 & 8 & 54 & & \\
\hline \multirow[t]{4}{*}{ NE Atlantic } & Svalbard & ES & 1998 & 15 & 1 & 16 & 15 Мay-31 Мay & 1 \\
\hline & Barents Sea & EB & 1998 & 30 & 3 & 33 & 23 May-25 June & 1 \\
\hline & Vesterålen/Lofoten & $\mathrm{EC}$ & 1998 & 8 & 6 & 14 & 28 May-14 August & 1 \\
\hline & Total & & 1998 & 53 & 10 & 63 & & \\
\hline North Sea & North Sea & EN & 1998 & 14 & 9 & 23 & 15 May-8 June & 1 \\
\hline
\end{tabular}

at Jan Mayen (CM), Svalbard (ES), in the Barents Sea (EB), at Vesterålen/Lofoten (EC) in northwestern Norway, and in the North Sea (EN) (Table 1, Fig. 1). All samples from the Norwegian catches were taken relatively early in the season (between 15 May and 1 July) except for Vesterålen/Lofoten, where samples were collected between 28 May and 14 August. The seasonal and spatial distribution of the samples in the present study are representative of the overall seasonal and spatial distribution of the Greenland (L. Witting, Greenland Inst. Nat. Res. unpubl. data) and Norwegian catches in 1998 (N. Øien, Mar. Res. Inst., Bergen unpubl. data).

All samples were stored at $-20^{\circ} \mathrm{C}$ until they were processed in the laboratory in Denmark.

(2) The second set of samples consisted of muscle tissue collected in Greenland by scientists (Larsen \& Kapel 1983) in 1982, and by licensed minke whale hunters in 1996, 1997 and 1999 (E. W. Born, Greenland Inst. Nat. Res. unpubl. data). Because of an annual quota of a maximum of 15 whales in area CG (East Greenland), too few samples were collected in East Greenland within 1 year. Hence, this area was represented by a combination of samples $(n=30)$ from 1996, 1997 and 1999. To test for potential inter-annual effects, samples collected in West Greenland in 1982, 1996 and 1997 were included in the analyses. The 1982 samples were collected by a Norwegian small-type whaler which operated offshore in western Greenland during the late 1970s and early 1980s (e.g. Larsen 1989). The East Greenland samples were collected between 12 July and 16 October with the majority being taken in August and September. The West Greenland samples were collected between 15 April and 26 November (Table 1).

The 1982 samples were stored frozen at $-20^{\circ} \mathrm{C}$ from sampling until analysis. The samples from the other years were stored in $20 \%$ DMSO, and saturated salt solution, and kept frozen at $-20^{\circ} \mathrm{C}$ until analysis.

Total cell-DNA was extracted from the muscle tissue according to Andersen et al. (1997), and the sex of all individuals was determined according to Bérubé \& Palsbøll (1996a,b). For 9 whales in which a discrepancy between sex as reported by the collectors and that of the genetic analysis was found, the tissues were reanalysed twice. During the last analysis the DNA was re-extracted and the sex-determination procedure repeated. All 3 analyses gave the same result.

Haplotypes published by Bakke et al. (1996) representing the central part of the North Atlantic around Iceland and from the Barents Sea were included in the study.

Sequencing of the mtDNA control region. PCR amplification of a $500 \mathrm{bp}$ fragment of the mitochondrial control region was conducted using the oligonucleotide primers MT4 (light-strand) (Árnason et al. 1993) modified by addition of $-21 \mathrm{M} 13$ primer to the 5'end (5' -TGTAAAACGACGGCCAGTCCCTCCCTAAGACTCAAGGAAG-3') and Dlp5 (heavy-strand) (Baker et al. 1996) modified by addition of M13 reverse primer to the 5'end (5'-CAGGAAACAGCTATGACCCCATCGAGATGTCTTATTTAAGGGGAAC-3'). The PCR products were purified using a QIAQuick PCR purification kit prior to cycle sequencing. Standard M13 forward and reverse dye primers were used for cycle sequencing with AmpliTaq FS sequencing kit (Perkin-Elmer) following the recommendations by the manufacturer (Applied Biosystems). The products were precipitated and sequenced on an ABI PRISM 377 automated DNA sequencer. Each sample was sequenced in both directions and the sequences were aligned using Sequencer 2.06. The haplotype designation used follows Bakke et al. (1996). 
Microsatellite loci. A total of 16 microsatellite loci with either di- or tetramer repeat motifs (Table 2) were used in the analyses. The amplification conditions are given in Table 2. The microsatellites were detected and scored as described in Andersen et al. (1998). A new primer-sequence set for locus EV96 (5'-AGCTGAAGTTTGAACTAAATTATG-3', 5'-CTCTTGACCACTCAATTCTTGC-3') was designed from the EV96Mn humpback whale sequence (GenBank Accession No. G09076, Valsecchi \& Amos 1996) as the EV96 primer sequence given by Valsecchi \& Amos (1996) indicated the presence of a null-allele in the minke whale samples used in the present study.

Data analysis. At the mtDNA level, nucleotide and haplotype diversity (Nei 1987) was estimated using ARLEQUIN Software (Schneider et al. 1997). The population structure was examined by conventional $F$ - statistics from haplotype frequencies (Weir \& Cockerham 1984) and by $\Phi$ statistics including a genetic distance between the haplotypes in the different sampling areas (Excoffier et al. 1992). The genetic distance used between the mtDNA sequences was Kimura 2-parameter (Kimura 1980) distance measure with the gamma-distribution correction estimated from the data

Table 2. The 16 polymorphic DNA microsatellite loci used in the study of North Atlantic minke whales, the nucleotide repeats, annealing temperature $\left({ }^{\circ} \mathrm{C}\right)$ and allele sizes. PCR-conditions: denaturation at $95^{\circ} \mathrm{C}$ for $3 \mathrm{~min}, 7$ cycles of denaturation at $94^{\circ} \mathrm{C}$ for $45 \mathrm{~s}$, first annealing temperature for $30 \mathrm{~s}$, extension at $72^{\circ} \mathrm{C}$ for $5 \mathrm{~s} .30$ cycles of denaturation at $94^{\circ} \mathrm{C}$ for $45 \mathrm{~s}$, second annealing temperature for $30 \mathrm{~s}$, extension at $72^{\circ} \mathrm{C}$ for $10 \mathrm{~s}$, followed by $74^{\circ} \mathrm{C}$ for $10 \mathrm{~min}$ and cooling to $4^{\circ} \mathrm{C}$, or 35 cycles of denaturation at $94^{\circ} \mathrm{C}$ for $45 \mathrm{~s}$, annealing temperature for $30 \mathrm{~s}$, extension at $7^{\circ} \mathrm{C}$ for $10 \mathrm{~s}$ followed by $74^{\circ} \mathrm{C}$ for $10 \mathrm{~min}$ and cooling to $4^{\circ} \mathrm{C}$

\begin{tabular}{|c|c|c|c|}
\hline Locus & Repeat no. & $\begin{array}{l}\text { Annealing temp. } \\
\left({ }^{\circ} \mathrm{C}\right)\end{array}$ & Allele sizes \\
\hline $1 \operatorname{Igf}-I^{\mathrm{a}, \mathrm{b}}$ & 2 & $48 / 50$ & $144-162$ \\
\hline 2 GAAT400 & 4 & $48 / 54$ & $150-162$ \\
\hline 3 GATAO28 $^{\mathrm{c}}$ & 4 & $52 / 56$ & $144-232$ \\
\hline 4 GATA098 $^{\mathrm{C}}$ & 4 & $48 / 54$ & $78-98$ \\
\hline 5 GATA $417^{\mathrm{C}}$ & 4 & $47 / 49$ & $209-249$ \\
\hline 6 GT011 & 2 & $52 / 56$ & $108-126$ \\
\hline $7 E V 96^{\mathrm{e}}$ & 2 & $48 / 56$ & $244-276$ \\
\hline $8 E V 37^{\mathrm{f}}$ & 2 & $52 / 56$ & $181-219$ \\
\hline $9 E V 30^{f}$ & 2 & $48 / 54$ & $132-138$ \\
\hline $10 E V 94^{\mathrm{f}}$ & 2 & $48 / 56$ & $210-216$ \\
\hline $11 E V 1^{\mathrm{f}}$ & 2 & 60 & $139-175$ \\
\hline $12 E V 21^{\mathrm{f}}$ & 2 & $52 / 56$ & $102-124$ \\
\hline $13 r w 48^{g}$ & 2 & 55 & $117-127$ \\
\hline $14 r w 26^{g}$ & 2 & 55 & $164-182$ \\
\hline $15 r w 31^{g}$ & 2 & 51 & $118-122$ \\
\hline $16 \mathrm{sam} 25^{\mathrm{g}}$ & 2 & 55 & $200-218$ \\
\hline
\end{tabular}

(Kimura 1980, Jin \& Nei 1990). These estimates were all run for 10000 permutations over individual haplotypes among populations and tested using ARLEQUIN (Schneider et al. 1997).

The phylogenetic relationships of the haplotypes were estimated and depicted in a consensus tree of 1000 bootstrap replications constructed on the basis of Kimura 2-parameter distances. This was conducted in the SEQBOOT and DNADIST programs in the PHYLIP package (Felsenstein 1993) and the consensus tree was constructed using the neighbour-joining method in this package. Genetic diversity at the nuclear level was estimated as observed and expected heterozygosity and number of alleles per locus (Nei 1987). The tests for goodness of fit to the Hardy-Weinberg proportions were performed using GENEPOP (Raymond \& Rousset 1995) based on the hypothesis of heterozygote deficiency and in FSTAT (Version 2.9.3.2). All significance values of the parameters tested were computed using Fisher's exact test iterated 3000 times over loci with a Markov chain method (Guo \& Thompson 1992) and performed in GENEPOP. The population structure models based on microsatellite variation were analysed by testing for homogeneity of allele frequencies among populations using GENEPOP (Raymond \& Rousset 1995). Furthermore, the degree of population differentiation was analysed by $F_{\mathrm{ST}}$ (Weir \& Cockerham 1984, Weir 1990, Michalakis \& Excoffier 1996) as implemented in ARLEQUIN (Schneider et al. 1997) after 10000 permutations over loci. To obtain the maximum spatial genetic difference $\left(F_{\mathrm{ST}}\right)$ between the areas, 'female-only' analyses were conducted (Tiedemann et al. 2000). The $F_{\mathrm{ST}}$ estimator used is identical to Weir \& Cockerham's weighted average, $\hat{\theta}$, which estimates the proportion of variance in allele frequencies caused by a substructuring of the samples. The $F_{\mathrm{ST}}$-statistic is based on the assumption that observed differences can mainly be attributed to drift and gene flow (infinite mutation model) (Slatkin 1995, Michalakis \& Excoffier 1996).

The genetic distances between the hypothesised 4 minke whale sub-populations based on allele frequencies were estimated using the distance measure $\left(D_{\mathrm{C}}\right)$ of Cavalli-Sforza \& Edwards (1967). The tree was constructed in TREEVIEW (Page 1996) after bootstrapping 2000 times over loci in SEQBOOT in PHYLIP (Felsenstein 1993) and $D_{\mathrm{C}}$ was estimated in GENDIST. The sequential Bonferroni procedure was applied using a significance level of $5 \%$ whenever multiple tests were performed to give table-wide significance levels (Rice 1989). In Table 6 this has not been applied when looking at the overall estimates including all 4 samples at the same time.

In order to reveal inter-seasonal, inter-annual and geographical variation, the samples were compared 
hierarchically in the following manner: (1) WG samples from different years were tested for homogeneity pairwise; (2) the combined (all sampling years) West Greenland sample was sub-divided into a group caught relatively early in the season (May and June) and later (July to October) - these 2 groups were tested against each other to detect potential inter-seasonal effect on population structure; (3) the combined samples from WG were tested against the combined CG sample; (4) CG was tested against $\mathrm{CM}_{\text {; }}$ (5) all Norwegian samples $(\mathrm{CM}, \mathrm{ES}, \mathrm{EB}, \mathrm{EC}, \mathrm{EN})$ were tested against each other; (6) for the 1998 samples alone WG was tested against the NE Atlantic samples $(\mathrm{ES}+\mathrm{EB}+\mathrm{EC}) ;(7)$ variation amongst $\mathrm{WG}, \mathrm{CG}+\mathrm{CM}, \mathrm{ES}+\mathrm{EB}+\mathrm{EC}$ and $\mathrm{EN}$ was tested; and finally (8) to expand and improve regional and temporal comparisons the haplotype distributions described by Bakke et al. (1996) for the central North Atlantic region west and north of Iceland and the Barents Sea were tested against the haplotype distribution observed in the present study.

All tests were conducted with and without prior assumptions of statistical distributions of genotypes or haplotypes in order to avoid pooling of heterogeneous samples. The homogeneity tests (i.e. $\chi^{2}$-tests of Roff \& Bentzen 1989) were conducted using the MONTE program in the REAP package version 4.0 after 5000 permutations (McElroy et al. 1992)

The existence of population structure was explored using a Bayesian clustering method (Pritchard et al. 2000) which uses multilocus genotypes to infer population structure. The model assumes that $k$ populations exist, which are characterised by a specific set of allele frequencies at each locus. Individuals are assigned to the populations probabilistically. The model assumes Hardy-Weinberg equilibrium (HWE) and linkage equilibrium. If departures from HWE are detected the population is split into sub-populations. The posterior $k$ probabilities are estimated assuming uniform values of $k$ from 1 to 5 and are based on 100000 iterations of burn-in period and 1000000 iterations without using prior population information. Hence, the hypothesis of the existence of 1 single population was tested.

\section{RESULTS}

\section{Sex determination and sex composition}

The sex of all individuals was determined genetically. Mis-determination (or mis-reporting) of sex was detected in 5 minke whales from Greenland (3 individuals reported to be males were females, and 2 reported females were in fact males) and 4 minke whales from Norway ( 3 whales reported to be females were males, and 1 reported male was a female).
Overall, the total sample $(n=306)$ consisted of $79 \%$ females and $21 \%$ males (Table 1 ). The sex composition in the samples taken in different years (Table 1) in WG did not differ significantly $\left(\chi^{2}=1.26, p=0.73, \mathrm{df}=3\right)$. Furthermore, the proportions of females in the samples from WG, CG, CM, ES and EB did not differ significantly $\left(\chi^{2}=6.70, p=0.15, \mathrm{df}=4\right)$ from each other. Neither did the proportions of females in the EC and EN samples differ $\left(\chi^{2}=0.05, p=0.82, \mathrm{df}=1\right)$ from each other. However, the proportion of females in the combined sample from the northern areas (WG, CG, CM, ES and EB: $82 \%$ females) was significantly higher $\left(\chi^{2}=9.80, p=0.02, d f=1\right)$ than that in the combined sample from the southern areas (EC, EN: 59\% females). Overall, therefore, the samples reflected the known difference in distribution of the 2 sexes during the summer when females tend to occur farther north than males (Øien 1988, Horwood 1989).

Homogeneity tests conducted before combining subsamples and looking at the genetic differences at the mtDNA level and testing for HWE did not detect heterogeneous samples (data not shown).

\section{Polymorphism levels in D-loop sequences of mtDNA}

A total of 28 polymorphic sites were observed (GenBank Accession No. AF487467-AF487491) of which 4 were transversions, 5 were deletion/insertion events (1 deletion/insertion event of 'A', 'TA', 'ATA', 'TATA' and 'ATATA') and the rest were transitions. The 28 sites defined a total of 48 different haplotypes where haplotype $\mathrm{N} 1$ is shared and common among all sampling areas. Twenty-five of the 48 haplotypes were not observed by Bakke et al. (1996). Estimates of nucleotide diversity ranged from $0.47 \%$ in the EN and CM samples to $0.7 \%$ in the EN and EC sample, and the haplotypic diversity estimates ranged from 0.841 in the samples from CM and EB to 0.978 in EC. The observed haplotype distribution in the total samples and when stratifying into sex (only females shown) is given in Table 3.

A strict consensus tree showing the evolutionary relationship between the haplotypes genealogy is depicted in Fig. 2, where the A1 haplotype from the Antarctic minke whale (Bakke et al. 1996) was used as an outgroup. No geographically sub-structuring was found between the haplotypes as reflected by the few nodes supported by bootstrap values above $50 \%$.

\section{Microsatellite variation}

A total of 16 polymorphic microsatellite loci were identified in the minke whale samples from Greenland, 


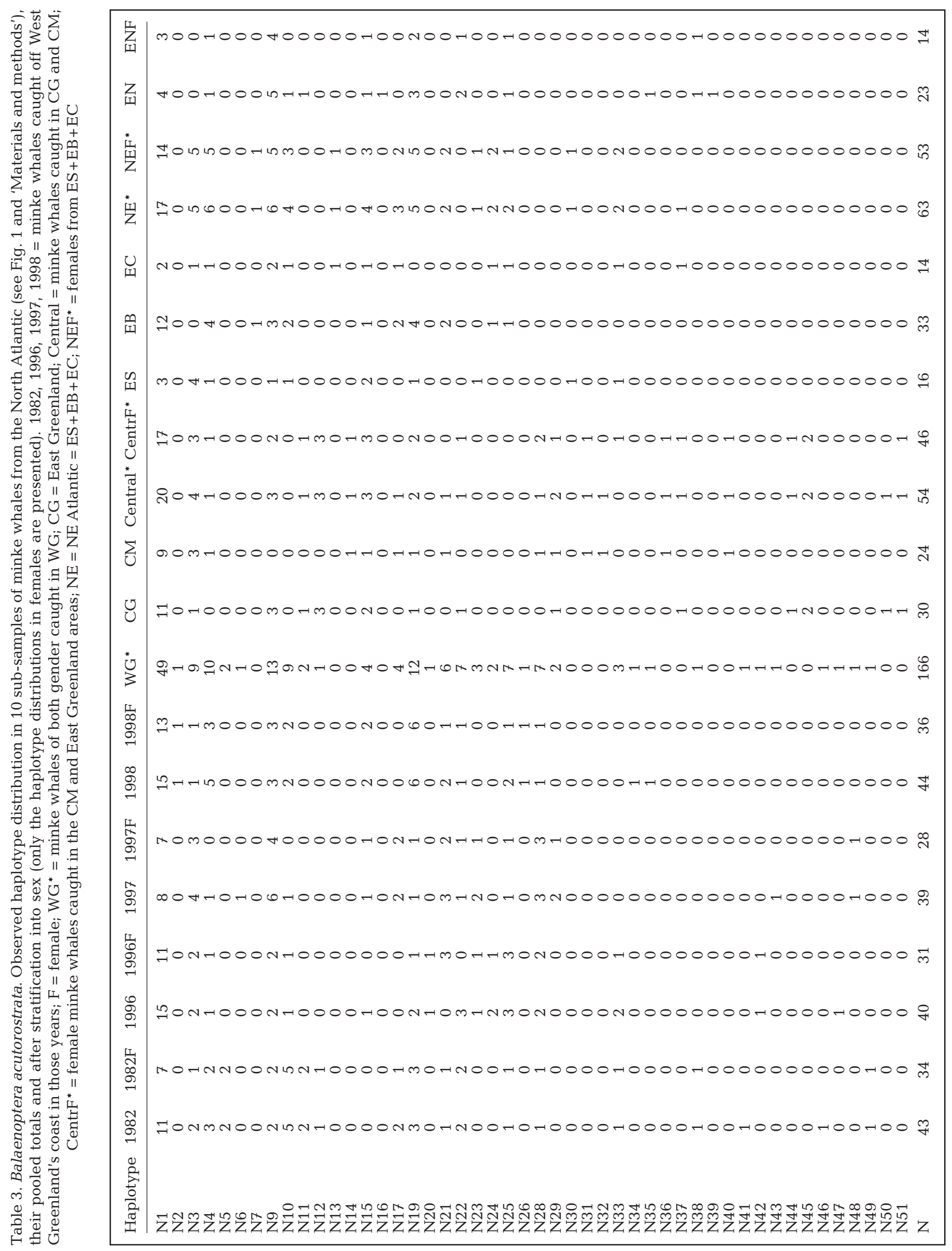




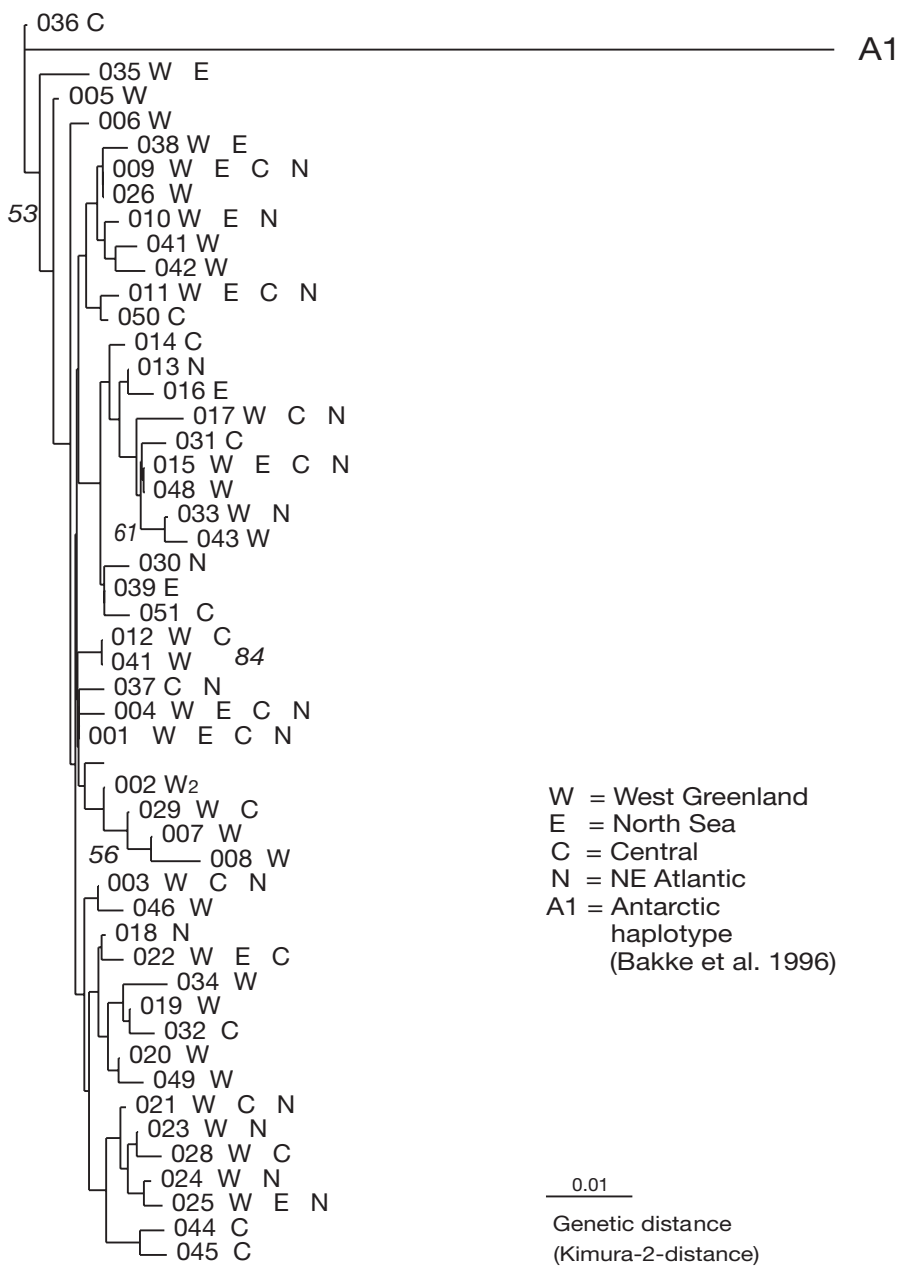

Fig. 2. Balaenoptera acutorostrata. Phylogenetic relationship, neighbour-joining and strict consensus tree of the detected haplotypes of North Atlantic minke whales after 1000 bootstrap replicates. Presence of haplotypes indicated by regional abbreviation in termini

the NE Atlantic Ocean and the North Sea. Genetic diversity measured by heterozygosity and number of alleles and tests for Hardy-Weinberg expectations are given in Table 4a for the total samples. Average mean observed heterozygosity based on the 16 loci ranged from 0.470 in WG (1996) to 0.554 in EC (1998); the latter sample had the lowest sample size. The averaged number of alleles ranged from 4.4 in the EC sample to 8.2 in the WG total sample (i.e. all years in WG combined). Significant deviations from the Hardy-Weinberg expectations were observed at locus EV96 in the CG sample, at locus EV21 in WG in 1982 and the WG total, at locus rw26 in WG in 1996, EB and pooled NE Atlantic sample (Table 4a) and at locus sam 25 in the pooled NE Atlantic female sample. The deviation at locus EV21 could probably be attributed to the WG 1982 sub-sample which was also observed in the female sample
(Table 4b). The deviation at locus rw26 in the NE Atlantic sample was probably caused by the EB sub-sample again reflected in the female sample (data not shown). The test for overall HWE across all loci indicated only limited significance after Bonferroni corrections in the pooled samples (Table $4 \mathrm{a}, \mathrm{b}$ ).

\section{Population structure analysed by D-loop mtDNA sequences and microsatellites}

The results of the tests exploring the population substructure in a hierarchical manner from comparisons of small areas to regions as outlined in 'Materials and methods: Data analysis' can be summarised as follows:

(1) and (2) No genetic sub-structuring at the mitochondrial level was detected in the West Greenland samples from 1982, 1996, 1997 and 1998 regardless of the approach (data not shown). Neither the genetic distance $\left(\Phi_{\mathrm{ST}}\right)$ testing the temporal differentiation nor the test for the spatial differentiation using the haplotype frequencies $\left(F_{\mathrm{ST}}\right)$ indicated significant differentiation among the samples. At the nuclear level (Table 5), the $F_{\mathrm{ST}}$ estimate and test for allele frequency differences indicated a temporal sub-structuring between the 1997 and 1998 samples. This tendency was not consistent, as it was not reflected in comparisons amongst the 1982, 1996 and 1997 samples or amongst the 1982, 1996 and 1998 samples (Table 5). The indicated sub-structuring was no longer apparent when the samples were partitioned by sex (data not shown). Furthermore, genetic differentiation was not observed when samples taken early in the season were compared to samples taken later in the season $\left(F_{\mathrm{ST}}=-0.002\right)$. Because inter-seasonal genetic variation was not detected and only low inter-annual variation was indicated, all samples from West Greenland were pooled in the further analyses.

(3) There was a difference between WG and CG females $\left(\Phi_{\mathrm{ST}}=0.035, \mathrm{p}=0.035\right)$, which indicated the existence of a small genetic difference between minke whales in these 2 areas. This difference was also reflected at the nuclear level in both the females $\left(F_{\mathrm{ST}}=0.005, \mathrm{p}=0.027\right)$ and the total sample (WG total-CG: $\left.F_{\mathrm{ST}}=0.005, \mathrm{p}=0.006\right)$. Hence, a low genetic difference between minke whales in western and eastern Greenland was indicated.

(4) Both at the mitochondrial and nuclear level there was no genetic difference detected between East Greenland (CG) and Jan Mayen, neither in the female sample nor in the total samples (data not shown), when testing for difference in haplotype distribution and allele frequency distribution and $F_{\mathrm{ST}}$, respectively. We therefore combined the samples from these 2 areas in the further analyses. 
(5) The analyses of genetic variation in the areas east of Greenland from 1998 did not detect significant differences at the mtDNA level among CM, EC, ES, EB, and EN samples. However, the analyses of the microsatellites resulted in significant $F_{\mathrm{ST}}$ values in the total samples between EN and ES $\left(F_{\mathrm{ST}}=0.025, \mathrm{p}=0.003\right)$, between EN and $\mathrm{CM}\left(F_{\mathrm{ST}}=0.017, \mathrm{p}=0.005\right)$, and between CM and ES $\left(F_{\mathrm{ST}}=0.025, \mathrm{p}=0.005\right)$. If looking only at the females, significant $F_{\mathrm{ST}}$ estimates were observed between EN and ES $\left(F_{\mathrm{ST}}=0.052, \mathrm{p}=0.0005\right)$, between $\mathrm{EN}$ and $\mathrm{EB}\left(F_{\mathrm{ST}}=0.029, \mathrm{p}=0.001\right)$, and between CM and ES $\left(F_{\mathrm{ST}}=0.031, \mathrm{p}=0.004\right)$. The tendency of the North Sea (EN) sample to deviate from the other sampling areas and the Jan Mayen (CM) sample to differ from the Svalbard (ES) sample caused us to separate these from the other 3 samples in the further analyses of population structure. Hence, the samples from ES, EB and EC were pooled to represent the minke whales that occur during summer in the NE Atlantic region (the combined sample was denoted 'NE Atlantic').

(6) When testing for genetic differences between minke whales occurring during the same year (i.e. 1998) in West Greenland and the 'NE Atlantic' (ES + EB + EC), we did not detect any significant difference at the mtDNA or the nuclear level, regardless of the analytical approach (i.e. haplotype distribution, allele frequency distribution and $F_{\mathrm{ST}}$ ).

(7) Our main hypothesis was that the minke whales within the different ecological regimes covered by the present study represent 4 genetically different sub-populations: a West Greenland (WG), a central $(\mathrm{CG}+\mathrm{CM})$, a NE Atlantic $(E S+E B+E C)$ and a North Sea (EN) sub-population. The results of the analysis of this hypothesis are given in Table 6. At the mtDNA level a significant $\Phi_{\mathrm{ST}}$ estimate was observed in the total sample (WG-Central-NE Atlantic-EN), in the total female sample (WG-CentralNE Atlantic-EN), and in the female sample between WG and the central group. At the nuclear level significant $F_{\mathrm{ST}}$ estimates and significantly different allele frequency distributions were observed between areas in all pair-wise comparisons of the total samples (Table 5). These differences were also reflected in the female samples and in both the overall samples (results of allele frequency differences not shown for the females and overall samples). When depicting the relationship among the 4 regions (Fig. 3) based on the allele frequencies and Cavalli-Sforza \& Edward's (1967) chord distance or using the pair-wise $F_{\mathrm{ST}}$ estimates, the West Greenland and Central North Atlantic samples clustered together.
(8) To test whether there was an inter-annual and inter-regional variation of the suggested 4 sub-populations (cf. 7) the results of a study by Bakke et al. (1996) based on mtDNA sequences of minke whales from the coastal waters north and west of Iceland (i.e. areas CIC and CIP pooled, Fig. 1) and the Barents Sea (EB) were included in the present study. No interannual variation was observed when Bakke et al.'s (1996) Barents Sea sample was compared to the present Barent's Sea sample (data not shown). As a result the 2 Barents Sea samples were pooled in the further analysis. Only the $\Phi_{\mathrm{ST}}$ estimate obtained from the analysis of the pooled West Greenland-Central-NE Atlantic-EN was significantly different from 0 $\left(\Phi_{\mathrm{ST}}=0.008, \mathrm{p}=0.024\right)$. This was not observed when testing for homogeneity in haplotype frequencies between these samples (data not shown). The sample representing the central North Atlantic (i.e. 'Central') consisted of the samples from CM (Jan Mayen) and CG (East Greenland) in the present study and from CIC and CIP in Bakke et al. (1996). The samples from these 4 areas were combined in the present analyses of regional differences as no difference in the haplotype distribution was observed among them (data not shown).

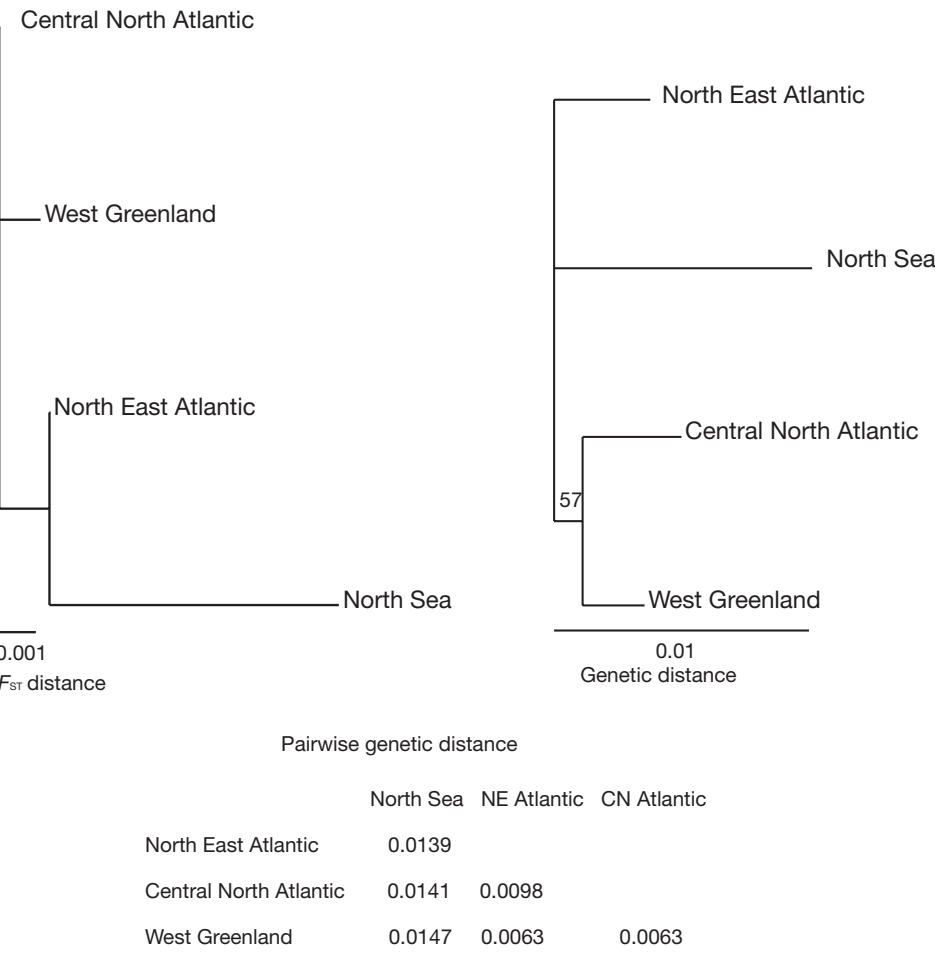

Fig. 3. Balaenoptera acutorostrata. Neighbour-joining population trees based on the pair-wise $F_{\mathrm{ST}}$ estimates and Cavalli-Sforza \& Edward's (1967) chord distance $\left(D_{\mathrm{C}}\right)$ of microsatellites when pooling the minke whale samples into a West Greenland, a Central, a NE Atlantic and a North Sea sub-population and bootstrapping 2000 times 


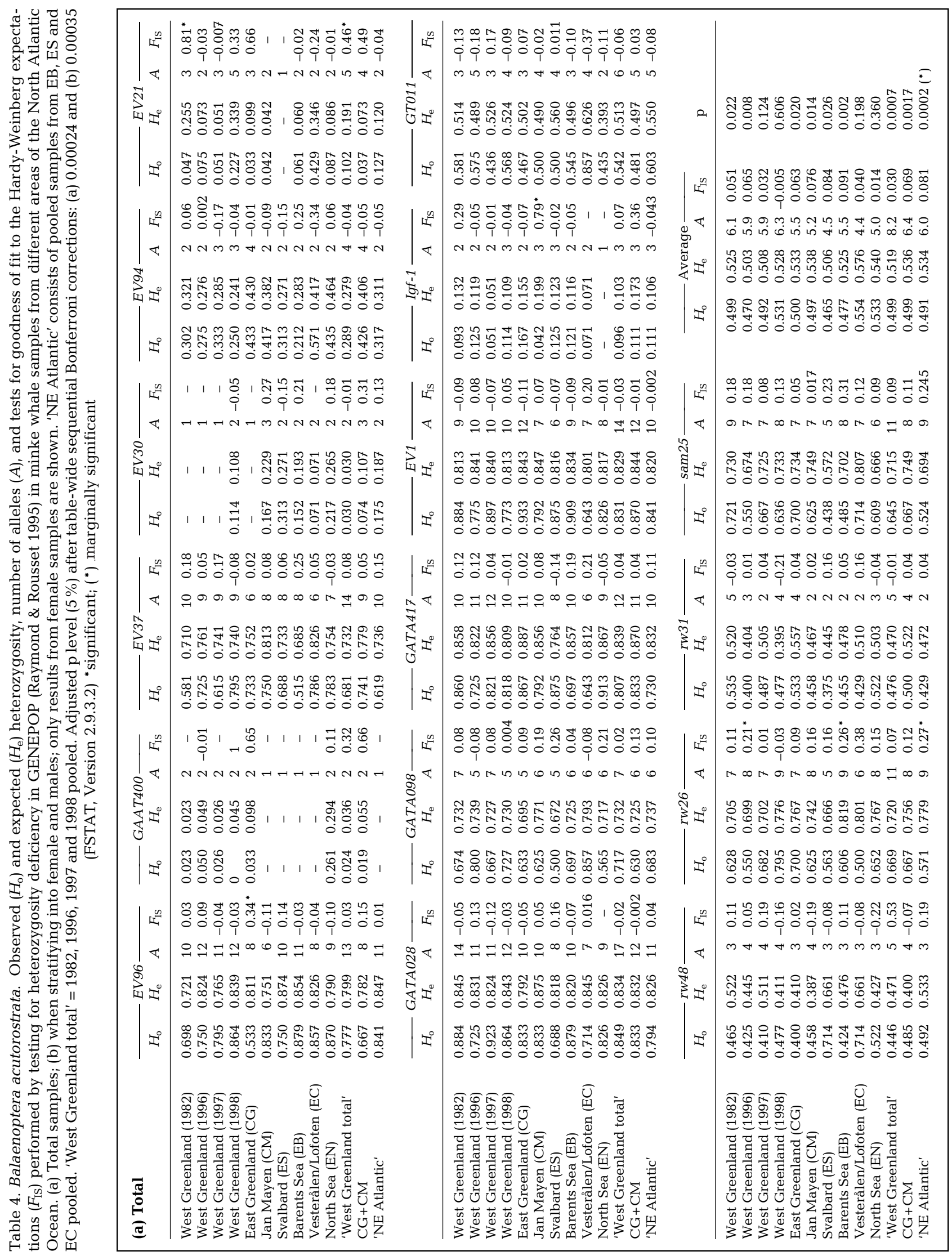




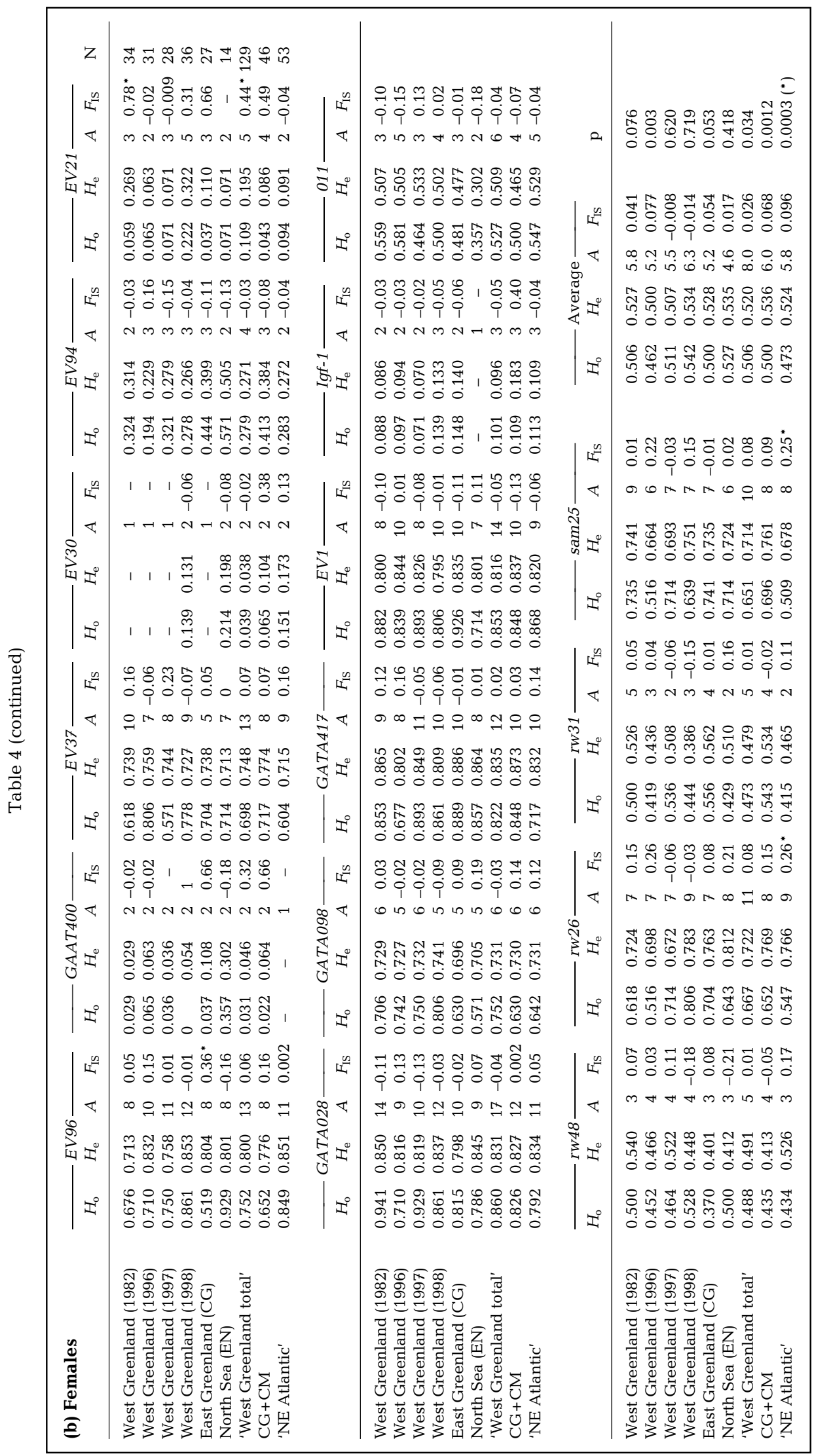


Table 5. Balaenoptera acutorostrata. Results of the tests for genetic differentiation of minke whales sampled during different years within the West Greenland area. Above diagonal: $\chi^{2}$ values $(\mathrm{df}=32)$ for the multilocus pair-wise tests for allele frequency differences estimated in GENEPOP (Raymond \& Rousset 1995). Below diagonal: results of the pair-wise multilocus $F_{\mathrm{ST}}$ tests between the sampling years

\begin{tabular}{|lllll|}
\hline & 1982 & 1996 & 1997 & 1998 \\
\hline 1982 & & 44.1 & 27.4 & 42.3 \\
1996 & 0.007 & & 44.7 & $58.4\left(^{*}\right)$ \\
1997 & 0.003 & 0.009 & & $55.4^{*}$ \\
1998 & 0.005 & 0.008 & $0.009^{* *}$ & \\
\hline
\end{tabular}

${ }^{*}$ Significant level $\mathrm{p}=0.003$ after Bonferroni correction at the $5 \%$ level (over 16 loci) for the test for allele frequency differences

$\left({ }^{*}\right)$ Marginally significant

** Significant level $\mathrm{p}=0.008$ after Bonferroni correction at the $5 \%$ level (over 16 loci) for the pair-wise multilocus $F_{\text {ST }}$ tests differences

\section{Analysis of population structure without a prior assumptions}

We also used a Bayesian clustering method (Pritchard et al. 2000) to analyse the population structure without any a priori assumption of regional differentiation. This corresponds to testing a null hypothesis that all samples belonged to one single population. If the single pooled sample is admixed (i.e. consists of more than one population) the likelihood (Ln-probability) will increase with the specific $k$ (i.e. number of subpopulations contained). The Ln probability obtained for the assumptions of $k=1$ to $k=5$ was $(k=1$ : Ln $=-11442.3, k=2:$ Ln $=-11318.3, k=3$ : Ln $=-11259.4, k=4:$ Ln $=-11260.0, k=5: \operatorname{Ln}=$ -11259.9). According to Akaike information criterion statistics (Sakamoto et al. 1943) this suggests that the combined sample of North Atlantic minke whales was heterogeneous and probably consisted of at least 3 different sub-populations.

\section{DISCUSSION}

\section{Genetic diversity at the mtDNA and microsatellite levels}

The mean nucleotide diversity observed in the present study (0.005 to 0.007) corresponds well to 0.0072 (Palsbøll et al. 1995) and 0.0064 (Bakke et al. 1996) reported for minke whales in the North Atlantic. Compared to that of Antarctic minke whales, 0.0159 (Bakke et al. 1996), mtDNA diversity in North Atlantic minke whales was substantially lower. The minke whales in the North Atlantic and in Antarctica are considered to be 2 different species, Balaenoptera acutorostrata and B. bonarensis, respectively (Rice 1998). The average heterozygosity observed at the 16 microsatellite loci (Table $4 \mathrm{a}, \mathrm{b}$ ) found in the present study was considerably higher than the heterozygosity levels obtained from allozyme data. Danielsdóttir et al. (1992) examined 36 allozyme loci in a total of 173 minke whales representing the suggested West Greenland, Central, and NE Atlantic sub-populations. The observed heterozygosity $\left(H_{0}\right)$ ranged from 0.080 to 0.580 (6 polymorphic loci) in the West Greenland sample, from 0.096 to 0.450 (6 polymorphic loci) in the Central and from 0.083 to 0.417 (5 polymorphic loci) in the NE Atlantic sample (Danielsdóttir et al. 1992). The difference in heterozygosity found in the 2 studies was probably caused by the higher mutation rate of the microsatellite loci $\left(10^{-3}\right.$, Weber \& Wong 1993) compared to protein coding loci such as allozymes $\left(10^{-9}\right.$, Nei 1987).

\section{Population structure}

At the mtDNA level there was no relationship between the different haplotypes (Fig. 2) and geographical areas. At the microsatellite level the significant deviations from the Hardy-Weinberg expectations in terms of heterozygote deficiency found in all the Norwegian and Greenland samples could be an effect of non-random mating, a Wahlund effect or null-alleles (Table $4 \mathrm{a}, \mathrm{b}$ ). If null-alleles were present we would expect a consistent pattern over the locus in question. This was not observed at any of the loci and furthermore all individuals amplified in the PCR reactions (i.e. no homozygote for null-alleles). We therefore consider the null-allele effect unlikely. The other effects mentioned cannot be excluded from the present study. We did not detect any significant inter-annual difference between samples from West Greenland. Although the samples were relatively small, but the number of analysed loci relatively high, this lack of difference suggests that minke whales caught in West Greenland in different years might belong to the same subpopulation. All West Greenland samples were concomitantly pooled to add power to the further geographical comparisons.

We stratified the minke whale data according to sex in order to analyse the population structure reflected in females separately. In a simulation study based on 2 large mammals (the blue whale Balaenoptera musculus, and the Asian elephant Elephas maximus), Tiedemann et al. (2000) illustrated that at the nuclear DNA level an increase in female migration will influence the population structure significantly more than an 
identical increase in male migration. In other words, one may expect that the $F_{\mathrm{ST}}$ values obtained by testing female samples would reflect the maximum spatial genetic differentiation of the minke whales.

This was shown in humpback whales worldwide, where Baker et al. (1994) detected a population structure in the maternally inherited mitochondrial DNA. Based on a RFLP study of the mtDNA, Baker et al. (1994) demonstrated that humpback whales show strong fidelity to migration destinations such as feeding grounds. They explained this to be a result of a transmission of feeding and migration strategies from mother to calf. Although Baker et al. (1994) detected low genetic sub-structuring between humpbacks from 2 nearby feeding grounds (the southern Gulf of Maine and Newfoundland), the heterogeneity between haplotype distribution on the 2 feeding grounds, together, and the Dominican Republic implied some genetic divergence in the western North Atlantic. Palsbøll et al. (1995) observed significant genetic differences between humpbacks from 2 North Atlantic feeding grounds, i.e. the western North Atlantic and Iceland.

Table 6. Balaenoptera acutorostrata. Results of tests for population sub-structuring in North Atlantic minke whales assuming an $H_{0}$ : 'North Atlantic minke whales constitute 1 coherent population' and an $H_{1}$ 'Due to the existence of different ecological regimes the North Atlantic minke whales are divided into 4 genetically different sub-populations: a West Greenland, a Central $(C G+C M), N E$ Atlantic $(E S+E B+E C)$ and a North Sea $(E N)^{\prime}$. (a) Total samples; (b) females. *Significant at the $5 \%$ level after application of the sequential Bonferrroni procedure; $\left(^{*}\right)$ significant at the $5 \%$ level but not $1 \%$ level after application of the sequential Bonferroni procedure ${ }^{* * *}$ not Bonferroni corrected

(a) Total

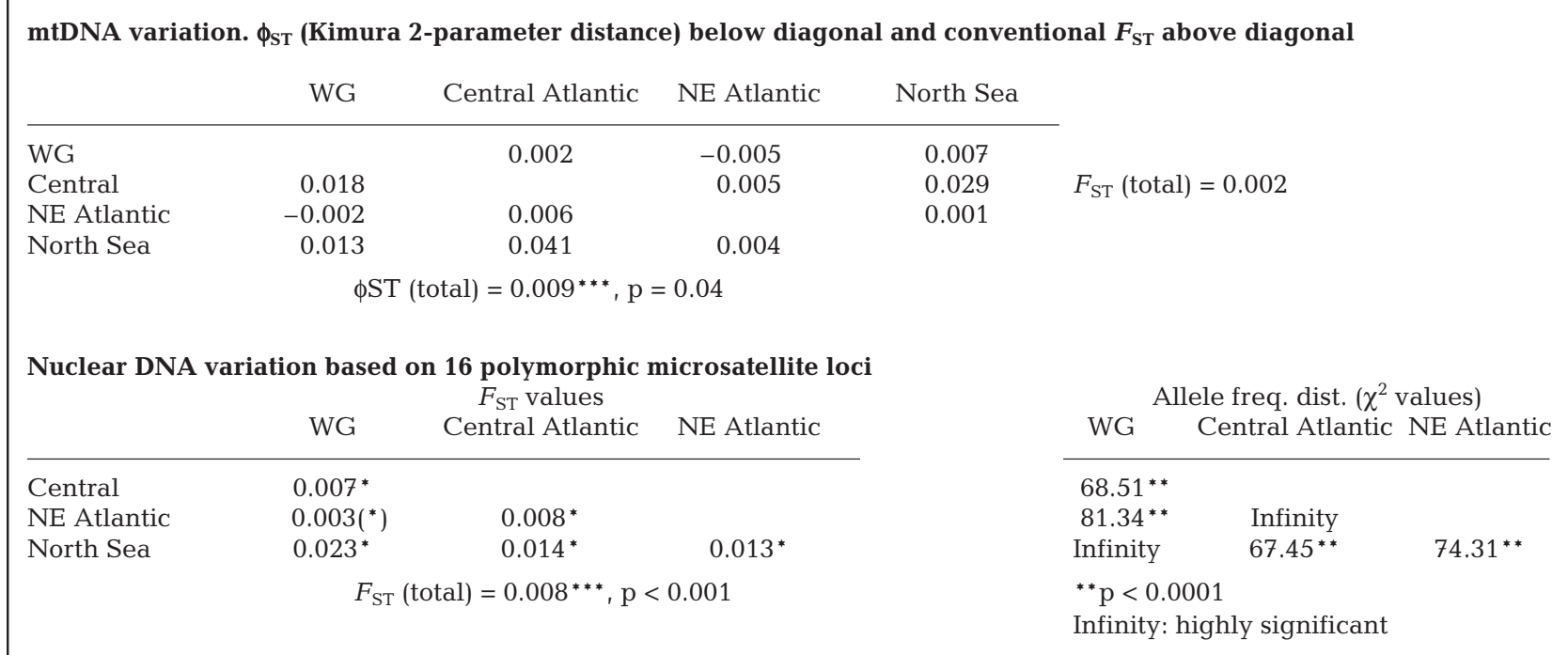

(b) Females

mtDNA variation. $\phi_{\mathrm{ST}}$ (Kimura 2-parameter distance) below diagonal and conventional $F_{\mathrm{ST}}$ above diagonal

\begin{tabular}{lcccrr} 
& WG & Central Atlantic & NE Atlantic & North Sea & \\
\cline { 1 - 2 } & & 0.003 & -0.005 & 0.002 & \multirow{2}{*}{$F_{\text {ST }}$ (total) $=0.0007$} \\
Central & $0.031^{*}$ & & 0.005 & 0.025 & \\
NE Atlantic & -0.0001 & 0.007 & & -0.004 &
\end{tabular}

North Sea $\quad-0.003 \quad 0.040 \quad-0.005$

$$
\phi_{\mathrm{ST}}(\text { total })=0.012^{* * *}, \mathrm{p}=0.04
$$

Nuclear DNA variation based on 16 polymorphic microsatellite loci

\begin{tabular}{|c|c|c|c|}
\hline & WG & $\begin{array}{c}F_{\mathrm{ST}} \text { values } \\
\text { Central Atlantic }\end{array}$ & NE Atlantic \\
\hline Central & $0.007^{*}$ & & \\
\hline NE Atlantic & $0.004\left(^{*}\right)$ & $0.011^{*}$ & \\
\hline \multirow[t]{2}{*}{ North Sea } & $0.034^{*}$ & $0.019^{*}$ & $0.033^{*}$ \\
\hline & $F_{\text {ST }}$ (total) & $.011^{* * *}, p<0.001$ & \\
\hline
\end{tabular}


The results of the hierarchial population analyses (1) and (2) indicated an apparent lack of temporal influence on the population structure of West Greenland minke whales. This lack was also observed in an allozyme study by Daníelsdóttir et al. (1995). In addition, the present study did not detect any seasonal effect on the population structure of West Greenland minke whales when samples taken during spring and early summer were tested against samples taken later in the season. Finally, the 1982 sample, which was taken offshore, did not differ from those taken inshore in West Greenland. Hence, the present study indicated that there is not an immigration of genetically different groups of minke whales to West Greenland waters during the season, and that the minke whales occurring offshore in 1982 were not genetically different from those occurring inshore in other years.

(3) The indications of genetic differences between minke whales in West Greenland and East Greenland (CG) seen at the nuclear level in the total and female samples and at the mtDNA level in the female samples are somewhat surprising. Ecologically, there is a connection between the West Greenland and SE Greenland marine waters. The East Greenland and the Irmiger Currents bring water from the eastern coast of Greenland to West Greenland, and there is a connection between the marine fauna on each side of Kap Farvel (i.e. the southern tip of Greenland). For example, fish eggs and larvae (e.g. Atlantic cod Gadus morrhua and Greenland halibut Reinhardtius hippoglossoides) are transported from east to west, whereas there is an active migration of adult fish in the opposite direction (Buch et al. 1994, Boje 2002). Aerial surveys conducted during summer indicate that the distribution of minke whales is apparently a continuum around Kap Farvel (cf. Anonymous 1998) and one would expect this mobile species to travel readily between the 2 areas during summer. On the basis of information on sex ratio in the historical catches in the West Greenland and the East Greenland-Iceland area and oceanographic conditions, it was considered unlikely that Kap Farvel is a good borderline in the sense of biological separation of populations of minke whales between West and East Greenland (Kapel 1980, Larsen \& Øien 1988). One explanation for the finding in the present study of 2 genetically different sub-populations of minke whales in West and East Greenland could be that the minke whales from East Greenland constitute a part of the Central North Atlantic stock or sub-population. This explanation was actually suggested by the analysis of population structure in this study (see 4 below) and also by the results of 2 isozyme studies by Danielsdóttir et al. (1992, 1995), who observed significantly different allele frequencies between minke whales from West Greenland and Ice- landic waters. The latter group is thought to be a part of the Central North Atlantic sub-population.

West Greenland minke whales might be related to minke whales summering along eastern Canada, but this has not been studied. However, a genetic study of fin whales Balaenoptera physalus, which have a very similar distribution in the North Atlantic, indicated that fin whales that summer in West Greenland could be from the same stock as those in the Gulf of Maine and Gulf of St. Lawrence (Bérubé et al. 1998). Therefore, it cannot be excluded that a connection exists between minke whales across the Davis Strait (Fig. 1).

(4) We did not detect any significant difference in mitochondrial or nuclear DNA between the samples from East Greenland (CG) and Jan Mayen. A likely explanation of this is that whales from these areas belong to the same sub-population (i.e. the Central North Atlantic sub-population; Anonymous 1993).

(5) At the mtDNA level, the samples taken east of Greenland (i.e. in CM, ES, EB, EC and EN) did not differ significantly, whereas at the microsatellite level, the overall test for sub-structure $\left(F_{\mathrm{ST}}\right)$ in both the total and the female samples indicated some genetic structuring. This sub-structuring could be attributed to the North Sea (EN) sample, the Jan Mayen (CM) and the Svalbard (ES) sample. However, the ES sample was very small and therefore like the Barents Sea (EB) sample poorly represented the allele frequency distribution of the sub-population in question, whereas the differences between the Jan Mayen and North Sea samples appeared to be real. Our finding that samples from Svalbard, the Barents Sea and the northwestern coast of Norway were not genetically different at either the mtDNA or the nuclear level is contradictory to the findings in the RAPD study of Martinez \& Pastene (1999). These researchers found indications of the existence of 2 closely related groups of minke whales in the North Atlantic: one in the eastern areas comprising the North Sea, Lofoten-Vesterålen and Barents Sea and another more central group consisting of minke whales from Jan Mayen and Svalbard. This apparent contradiction can be a result of the different pooling of samples from the various areas, the difference in sample sizes, and the fact that the samples in the present study were taken within the same year, which was not the case in the study by Martinez \& Pastene (1999).

(6) The lack of genetic differentiation in the present study between WG minke whales and those caught in ES, EB, and EC in 1998 is in accordance with findings of Bakke et al. (1996). These authors did not detect any sub-structuring in the analysis of D-loop sequences among minke whales in the NE Atlantic region nor between the suggested Central (Icelandic) subpopulation and the Barents Sea sub-population. In a 
RFLP study of mtDNA and rDNA, Palsbøll (1989) did not detect differences between WG and EN samples. However, the lack of differentiation in his study could most likely be attributed to the low sample size from the EN area $(n=9)$. Nonetheless, in all these cases it cannot be excluded that the failure to detect population sub-structure was caused by a combination of low sample sizes and low resolution of the techniques applied. This may to some extent also have been the case in the present study.

(7) The differences expressed at the nuclear level suggested the grouping of the North Atlantic minke whales into 4 ecologically based sub-populations. All pair-wise comparisons were significantly different, indicating the existence of a West Greenland, a Central, a NE Atlantic and a North Sea sub-population. The differentiation was reflected both in the total and in the female samples. The relationship depicted in Fig. 3 indicated a relatively close relationship between the West Greenland sample and the Central North Atlantic sample $(\mathrm{CG}+\mathrm{CM})$. This was especially expressed in the tree based on the $F_{\mathrm{ST}}$ estimates, where the branch lengths can be considered significantly different from 0 . This relationship was not surprising given the distance between sampling areas. The observation of 4 genetically different sub-populations was partly supported by the results of the mtDNA analyses. Here, only the overall $\Phi_{\mathrm{ST}}$ estimates for the total and female samples were significantly different from 0 , suggesting that the sub-populations may have existed for some time. However, no relationship between geographical origin and haplotype was detected (Fig. 2). Considering the different mutation rates of the D-loop sequence and the microsatellites loci it is expected that the microsatellite analysis will be able to detect more detailed or more contemporary subpopulation differentiation as also illustrated in the present study.

(8) The inclusion of Bakke et al.'s (1996) samples in our mtDNA analysis indicated some sub-structuring amongst the 4 sampling areas-West Greenland, Central North Atlantic, NE Atlantic and North Sea-hence supporting the results indicated by the nuclear DNA in the present study.

Without an a priori geographic grouping of the samples the Bayesian clustering procedure suggested the existence of at least 3 sub-populations. A likely reason why the fourth sub-population was not detected is the relatively low sample size in the North Sea.

Within each of the sampling areas, except western Greenland, the individual sampling locations were relatively narrowly clustered compared to the apparently more even distribution of minke whales within the range studied (cf. Anonymous 1998). Theoretically, such geographically concentrated sampling would tend to emphasise differences between areas. Nevertheless, the samples from the areas east of Greenland, except Jan Mayen and the North Sea, did not differ genetically supporting the hypothesis that minke whales in the NE Atlantic may belong to the same subpopulation.

We suggest that the 4 genetically distinct groups of minke whales may have evolved different genetic compositions as a result of different ecological conditions prevailing in the oceans where they feed during summer, combined with a strong affiliation between mother and calf and feeding site as observed in the humpback whale (Baker et al. 1994) and suggested by Tiedemann et al. (2000) for the blue whale. The fact that the genetic pattern is only observed at the nuclear level and not at the mtDNA level can probably be attributed to the relatively short divergence time which can be approximately dated back to the end of the last ice age (i.e. about 10000 years ago; Dansgaard et al. 1993). After such a relatively short time span one cannot expect to observe differences at the mtDNA level due to the high dispersal ability of the species and the relatively slow mutation rate of the D-loop. However, it would seem that the suggested 4 major ecological regions have remained almost unchanged since the last ice age, as indicated by the marine micropaleontological record obtained from the planktonic and benthic foraminifera faunas of the areas (Koc et al. 1993, Rasmussen et al. 2002).

Differences in ice conditions, current patterns, food type and the availability thereof may impose different selective forces on the minke whales at their North Atlantic summering grounds. The distribution and population structure of the minke whales on their wintering areas are unknown (cf. Horwood 1989) and therefore it is not known if the distribution during the mating season of the whales from the different summering grounds is allopatric or sympatric. If the distribution is sympatric on the wintering grounds one may accept sympatric speciation (cf. Dieckmann \& Doebeli 1999, Stearns \& Hoekstra 2000) with selective forces primarily being active on the summering grounds. If the winter distribution is allopatric it suggests the existence of 4 different wintering areas or breeding areas. The existence of major ecological differences between regions is in accordance with other studies using the same material from 1998 but applying different analytical techniques. A regional comparison of PCBs and organochlorine $(\mathrm{OC})$ pesticides in blubber (Hobbs et al. 2003), fatty acid profiles (Møller et al. 2003), concentrations of various elements in soft tissues and baleen (Born et al. unpubl. data), and concentrations of caesium-137 in muscle (Born et al. 2002) revealed some differences among sampling areas. Although in 
some cases these studies grouped the samples differently, they indicated that minke whales in West Greenland and the North Sea to be markedly different from those in the other areas.

In conclusion, the results of the present study explain to a certain extent the non-coherent results obtained from earlier studies of the North Atlantic minke whale based on allozymes, RFLP on mtDNA, RAPD and DNAfingerprinting. The finding of 4 genetically different minke whale groups in seas that are ecologically substantially different suggests that this genetic variation has evolved as a response to different selective forces acting on the summering grounds. Minke whales from Canadian (WC) and Icelandic (CIP and CIC, cf. Fig. 1) waters were not included in the present study. According to Horwood (1989) there was no evidence to support a difference between the Canadian and West Greenland stock. On the contrary, the timing of previous catches (Canada stopped whaling after the 1972 season) indicated that the whales migrate past Newfoundland, and as the season progresses may be caught further north off West Greenland (ibid.). However, we recommend that future studies of minke whale population structuring in the North Atlantic region include samples taken (including biopsies from Canada and Iceland) in a given year in all areas of the species range.

Acknowledgements. This study was funded by the Danish Ministry of the Environment (Program: DANCEA 'Danish Cooperation for Environment in the Arctic') and the Greenland Institute of Natural Resources. We wish to thank the Greenland and Norwegian fishermen and hunters and others who helped with collecting the samples. The co-operation during the sampling phase with the Directorate of Fisheries (Nuuk) and KNAPK (Association of Greenland Hunters and Fishermen) is greatly acknowledged. Thanks to Sofie Jeremiassen and Kirsten Rydahl (the Greenland Institute of Natural Resources) and to Sigga Joensen, Else Marie Nielsen, and Maja Kirkegaard (Danish Environmental Research Institute, Roskilde) for various help during the sampling and preparation of the samples. We thank Dr. Tony Fox (Dept of Coastal Zone Ecology, Denmark), for comments and helping with the language and the anonymous referees for offering useful comments on a draft of this paper.

\section{LITERATURE CITED}

Andersen LW, Holm LE, Siegismund HR, Clausen B, Kinze CC, Loeschcke V (1997) A combined DNA-microsatellite and isozyme study of the population structure of the harbour porpoise in Danish waters and West Greenland. Heredity 78:270-276

Andersen LW, Born EW, Gjertz I, Wiig Ø, Holm LE, Bendixen C (1998) Population structure and gene flow of the Atlantic walrus, Odobenus rosmarus rosmarus, in the eastern Atlantic Arctic based on mitochondrial DNA and microsatellite variation. Mol Ecol 7:1323-1336

Anonymous (1992) Annex K, Report of the working group on North Atlantic minke trials. Rep Int Whal Commn 42 $246-251$

Anonymous (1993) Report of the sub-committee on North Atlantic baleen whales, annex F. Rep Int Whal Commn 44:115-224

Anonymous (1998) Report of the scientific committee working group on abundance estimates, annex 3 . Report of the fifth meeting of the scientific committee, Tromsø, Norway, 10 to 14 March 1997. In: NAMMCO Annual Report 1997, North Atlantic Marine Mammal Commission Tromsø, p 85-202

Árnason A, Spillaert R (1991) A study of variability in minke whales (Balaenoptera acutorostrata) in the North Atlantic using a human hypervariable region probe, alpha-globin 3'HVR. Rep Int Whal Commn 41:439-443

Árnason U, Gullberg A, Widegren B (1993) Cetacean mitochondrial DNA control region: sequences of all extant baleen whale and two sperm whale species. Mol Biol Evol 10:960-970

Baker CS, Slade RW, Bannister JL, Abernethy RB and 7 others (1994) Hierarchical structure of mitochondrial DNA gene flow among humpback whales, Megaptera novaeangliae, world-wide. Mol Ecol 3:313-327

Baker CS, Cipriano F, Palumbi SR (1996) Molecular identification of whale and dolphin products from commercial markets in Korea and Japan. Mol Ecol 5:671-685

Bakke I, Johansen S, Bakke Ø, El-Gewely MR (1996) Lack of population subdivision among minke whales (Balaenoptera acutorostrata) from Icelandic and Norwegian waters based on mitochondrial DNA sequences. Mar Biol 125:1-9

Bérubé M, Palsbøll PJ (1996a) Identification of sex in cetaceans by multiplexing with three ZFX and ZFY specific primers. Mol Ecol 5:283-287

Bérubé M, Palsbøll PJ (1996b) Erratum of identification of sex in cetaceans by multiplexing with three ZFX and ZFY specific primers. Mol Ecol 5:602

Bérubé M, Aguilar A, Dendanto D, Larsen F and 5 others (1998) Population genetic structure of North Atlantic, Mediterranean Sea and Sea of Cortez fin whales, Balaenoptera physalus (Linnaeus 1758): analysis of mitochondrial and nuclear loci. Mol Ecol 7:585-599

Boje J (2002) Intermingling and seasonal migrations of Greenland halibut stock components in the Northwest Atlantic based on tagging studies. Fish Bull 100:414-422

Born EW, Dahlgaard H, Riget FF, Dietz R, Haug T, Øien N (2002) Regional variation of caesium-137 in minke whales Balaenoptera acutorostrata from West Greenland, the Northeast Atlantic and the North Sea. Polar Biol 25: 907-913

Buch E, Horsted SA, Hovgaard H (1994) Fluctuations in the occurrence of cod in Greenland waters and their possible causes. ICES Mar Sci Symp 198:158-174

Cavalli-Sforza LL, Edwards AWE (1967) Phylogenetic analysis: models and estimation procedures. Evolution 32: 550-570

Danielsdóttir AK, Duke EJ, Àrnason A (1992) Genetic variation at enzyme loci in the North Atlantic minke whale, Balaenoptera acutorostrata. Biochem Genet 30(3/4): 189-202

Danielsdóttir AK, Halldórsson SD, Gudlaugsdóttir S, Àrnason A (1995) Genetic variation in Northeastern Atlantic minke whales (Balaenoptera acutorostrata). In: Blix AS, Walløe L, Ulltang $\varnothing$ (eds) Developments in Marine Biology 4, Whales, seals, fish and man. Elsevier, Amsterdam, p 105-118

Dansgaard W, Johnsen SJ, Clausen HB, Dahl-Jensen D and 7 others (1993) Evidence for general instability of past climate from a 250-kyr ice-core record. Nature 364:218-220 
Dieckmann U, Doebeli M (1999) On the origin of species by sympatric speciation. Nature 400:354-356

Excoffier L, Smouse PE, Quattro JM (1992) Analysis of molecular variance inferred from metric distances among DNA haplotypes: application to human mitochondrial DNA restriction data. Genetics 131:479-491

Felsenstein J (1993) PHYLIP Version 3.5c. Phylogeny inference package. Dept of Genetics, University of Washington, Seattle

Folkow LP, Haug T, Nilssen KT, Nordøy E (2000) Estimated food consumption of minke whales Balaenoptera acutorostrata in Northeast Atlantic waters in 1992-1995. In: Víkingsson GA, Kapel FO (eds) Minke whales, harp and hooded seals: major predators in the North Atlantic ecosystem, Vol. 2. NAMMCO Scientific Publications, Tromsø, p 65-80

Guo SW, Thompson EA (1992) Performing the exact test for Hardy-Weinberg proportion for multiple alleles. Biometrics 48:361-372

Haug T, Lindstrøm U, Nilssen KT (2002) Variations in minke whale, Balaenoptera acutorostrata, diet and body conditions in response to ecosystem changes in the Barents Sea. Sarsia 87 (in press)

Hobbs KE, Muir DCG, Born EW, Dietz R, Haug T, Metcalfe T, Metcalfe C, Øien N (2003) Levels and patterns of persistent organochlorines in minke whale (Balaenoptera acutorostrata) from the North Atlantic and European Arctic. Environ Pollut 121:239-252

Horwood J (1989) Biology and exploitation of the minke whale. CRC Press, Boca Raton, FL

Jin L, Nei M (1990) Limitations of the evolutionary parsimony method of phylogenetic analysis. Mol Biol Evol 7:82-102

Jonsgård A (1966) The distribution of Balaenopteridae in the North Atlantic Ocean. In: Norris KS (ed) Whales, dolphins and porpoises. University of California Press, Berkeley, CA, p 114-124

Kapel FO (1980) Sex ratio and seasonal distribution of catches of minke whales in West Greenland. Rep Int Whal Commn 30:195-199

Kasamatsu F, Nishiwaki S, Ishiwaki H (1995) Breeding areas and southbound migrations of southern minke whales Balaenoptera acutorostrata. Mar Ecol Prog Ser 119:1-10

Kimura M (1980) A simple method for estimating evolutionary rates of base substitutions through comparative studies of nucleotide sequences. J Mol Evol 16(2):111-20

Kirkpatrick BW (1992) Identification of a conserved microsatellite site in porcine and bovine insulin-like growth factor-I gene 5'flank. Anim Genet 23:543-548

Koc N, Jansen E, Haflidason H (1993) Paleoceanographic reconstructions of surface ocean conditions in the Greenland, Iceland and Norwegian seas through the last $14 \mathrm{ka}$ based on diatoms. Q Sci Rev 12:115-140

Larsen F (1989) Norwegian minke whaling at West Greenland: operational strategies. Rep Int Whal Commn 39: 249-251

Larsen F, Kapel FO (1983) Further biological studies of the West Greenland minke whale. Rep Int Whal Commn 33: 329-332

Larsen F, Øien N (1988) On the discreteness of stocks of minke whales at East and West Greenland. Rep Int Whal Commn 38:251-255

Mackintosh NA (1965) The stocks of whales. Coward \& Gerrish, Larkhall, Bath

Mann KH, Lazier JRN (1991). Dynamics of marine ecosystems. Biological-physical interactions in the oceans. Blackwell Scientific Publications, Boston, MA

Martinez I, Pastene L (1999) RAPD-typing of Central and
Eastern North Atlantic and Western North Pacific minke whales (Balaenoptera acutorostrata). ICES J Mar Sci 56: 640-651

Martinez I, Elvevoll EO, Haug T (1997) RAPD typing of northeast Atlantic minke whale (Balaenoptera acutorostrata). ICES J Mar Sci 54:478-484

McElroy D, Moran P, Bermingham E, Kornfield I (1992) REAP — an integrated environment for the manipulation and phylogenetic analysis of restriction data. J Hered 83: 157-158

Michalakis Y, Excoffier L (1996) A generic estimation of population subdivision using distances between alleles with special reference to microsatellite loci. Genetics 142: 1061-1064

Møller P, Born EW, Dietz R, Ruzzante D, Haug T, Øien N (2003) Differences in fatty acid composition of blubber in minke whales (Balaenoptera acutorostrata) from Greenland and the Northeast Atlantic. J Cetacean Res Manage (in press)

Nei M (1987) Molecular evolutionary genetics. Columbia University Press, New York

Neve PB (2000) The diet of the minke whale in Greenlanda short review. In: Víkingsson GA, Kapel FO (eds) Minke whales, harp and hooded seals: Major predators in the North Atlantic ecosystem, Vol. 2. NAMMCO Scientific Publications, Tromsø, p 92-96

Olsen E, Holst JC (2002) A note on common minke whale (Balaenoptera acutorostrata) diets in the Norwegian Sea and the North Sea. J Cetacean Res Manage 3(2):179-183

Øien N (1988) Length distributions in catches from the northeastern Atlantic stock of minke whales. Rep Int Whal Commn 38:289-295

Page RDM (1996) TREEVIEW: An application to display phylogenetic trees on personal computers. Comput Appl Biosci 12:357-358

Palsbøll PJ (1989) Restriction fragment pattern analysis of mitochondrial DNA in minke whales, Balaenoptera acutorostrata, from the Davis Strait and the Northeastern Atlantic. Master of Science thesis, University of Copenhagen

Palsbøll PJ, Clapham PJ, Mattila DK, Larsen F and 5 others (1995) Distribution of mtDNA haplotypes in North Atlantic humpback whales: the influence of behaviour on population structure. Mar Ecol Prog Ser 116:1-10

Palsbøll PJ, Berubé M, Larsen AH, Jørgensen H (1997) Primers for the amplification of tri and tetramer microsatellite loci in the baleen whales. Mol Ecol 6(9):893-895

Pritchard JK, Stephens M, Donnelly PJ (2000) Inference of population structure using multilocus genotype data. Genetics 155:945-959

Rasmussen TL, Thomsen E, Troelstra SR, Kuijpers A, Prins MA (2002) Millennial-scale glacial variability versus holocene stability changes in planktic and bentic foraminifera faunas and ocean circulation in the North Atlantic during the last 60000 years. Mar Micropaleontol 897:1-34

Raymond M, Rousset F (1995) GENEPOP Ver 3.2.: a population genetics software for exact tests and ecumenicism. J Hered 86:248-249

Rice DW (1998) Marine mammals of the world: systematics and distribution. Soc Mar Mamm Lawrence, KS, Spec Publ 4

Rice WR (1989) Analyzing tables of statistical tests. Evolution 43:223-225

Roff DA, Bentzen P (1989) The statistical analysis of mitochondrial DNA polymorphism: $\chi^{2}$ and the problem of small sample sizes. Mol Biol Evol 6:539-545

Sakamoto Y, Ishiguro M, Kitagawa G (1943) Akaike informa- 
tion criterion statistics. In: Hazewinkel M (ed) Mathematics and its applications KTK Scientific Publishers, Tokyo, p 56-85

Schneider S, Kueffer JM, Roessli D, Excoffier L (1997) ARLEQUIN Ver. 2.000: a software for population genetic data analysis. Genetics and Biometry Laboratory, University of Geneva

Slatkin M (1995) A measure of population subdivision based on microsatellite allele frequencies. Genetics 139:457-562

Stearns SC, Hoekstra RF (2000) Evolution: an introduction. Oxford University Press, Oxford

Tiedemann R, Hardy O, Vekemans X, Milenkovitch M (2000)

Editorial responsibility: Otto Kinne (Editor),

Oldendorf/Luhe, Germany
Higher impact of female than male migration on population structure in large mammals. Mol Ecol 9 (8):1159-1163

Waldick RC, Brown MW, White BN (1999) Characterization and isolation of microsatellite loci from endangered North Atlantic right whale. Mol Ecol 8:1753-1768

Valsecchi E, Amos W (1996) Microsatellite markers for the study of cetacean populations. Mol Ecol 5:151-156

Weber JL, Wong C (1993) Mutation of human short tandem repeats. Hum Mol Genet 2:1123-1128

Weir BS (1990) Genetic data analysis. Sinauer, Sunderland, MA Weir BS, Cockerham CC (1984) Estimating F-statistics for the analysis of population structure. Evolution 38:1358-1370

Submitted: July 4, 2001; Accepted: October 9, 2002

Proofs received from author(s): January 10, 2003 